\title{
Survival and Growth of Seedlings of Two Rhododendron Tree Species along an Altitudinal Gradient in a Temperate Broad Leaved Forest of Arunachal Pradesh, India
}

\author{
Sanjeeb Bharali ${ }^{1, *}$, Ashish Paul ${ }^{1}$, Mahamed Latif Khan ${ }^{1,2}$, Lal Bihari Singha ${ }^{1}$ \\ ${ }^{1}$ Department of Forestry, North Eastern Regional Institute of Science and Technology, Deemed University, \\ Nirjuli, Arunachal Pradesh, 791109, India \\ ${ }^{2}$ Department of Botany, Guru Ghasidas University, Koni Bilaspur, Chhattisgarh, 495009, India
}

\begin{abstract}
Seedling survival and growth of two Rhododendron species viz., Rhododendron kenderickii and Rhododendron grandewere studied along an altitudinal gradient in a temperate forest. Differences in survivality and relative growth responses of the two selected rhododendrons in terms of height, collar diameter and leaf number were monitored seasonally. High seedling mortality was recorded highest in winter season as well as in the higher altitude. Both the species attain maximum growth in terms of height, collar diameter and mean leaf number during rainy season while, minimum in winter season. Moreover, both the Rhododendron species exhibit variation in growth response with altitude and higher total growth was recorded in lower altitude. The result of the present study showed that the survival and growth of seedlings of both the selected Rhododendron species were greatly influenced by altitude as well as season. This variability may be due to the variation in light, temperature, moisture and edaphic factors in various seasons as well as at different altitudes, which results into development of an array of microclimatic conditions for differential growth behavior of different species.
\end{abstract}

Keywords Edaphic Factors, Moisture Stress, Light, Temperature, Seasons

\section{Introduction}

Forest community structure and composition may be largely determined at early life history stages. The most reliable indicator of successful restoration of forest communities is likely to be the number and composition of the woody seedlings colonizing naturally[1]. The seedling stage represents a demographic bottleneck for most populations[2]. Plant populations usually go through major thinning during the seedling phase and the traits that affect seedling survival vary according to environmental conditions[3,4]. Survival and growth of tree seedlings are determined by the interactive influence of biotic and abiotic factors of the forest environment[5]. High mortality at seedling stages further limit speciesdistributions[6-10]. Because species vary greatly in their sensitivities to mortality agents at early life history stages, spatially variable environments greatly affect community composition of seedlings[11-14]. Tree seedling dynamics is affected by various environmental factors $[15,16]$

* Corresponding author:

sanjeebbharali@yahoo.co.in (SanjeebBharali)

Published online at http://journal.sapub.org/plant

Copyright (C 2012 Scientific \& Academic Publishing. All Rights Reserved such as soil moisture[17,18], micro-scale disturbances[19,20] , canopy cover[21,22] and thickness of leaf litter layer[23-25].

Light is the primary regulator of seedling performance on the forest floor[26], but the importance of nutrients and water to seedling survival below a forest canopy remain poorly defined[27]. Light is also a resource that limits tree seedling recruitment in many forest understories and canopy gaps can raise light levels, leading to increased seedling recruitment and higher levels of species diversity[28-30]. Spatial patterns of light availability are likely to influence the spatial arrangement of plant species[31,32]. However, the indirect effects such as those mediated by soil and litter have also been proven to be important for seedling growth and survival in the understorey[33,34]. Litter is an important general factor determining the spatial variation in seedling recruitment. Thick litter layer generally reduces the rates of germination and of seedling establishment. However, herbaceous cover, rather than litter, has an even more adverse effect on seedling emergence, survival and growth[35,36]. Seasonality also affects patterns of seed production, germination, survival and seedling development[37]. In broad-leaved temperate deciduous forest, the variation in understorey light conditions is produced not only by spatial variation of overstorey structure, but also by temporal 
variation among species in timing of leaf emergence[38-40]. Enough light is usually available for the understorey plants prior to leaf emergence of canopy trees in early spring. The earlier leaf emergence in the tree seedlings, compared with canopy trees, is a crucial factor for their survival and growth[25,40,41].

Several studies have been conducted elsewhere on survival and growth of seedlings of various tree species in various natural as well as in experimental conditions, but did not relate to altitudinal gradient. A few studies have also been carried out on survival and growth of Rhododendron seedlings, but none of those studies were with respect to altitudinal gradient especially in Arunachal Pradesh. Hence, the present study has been carried out with an aim to analyse whether there is any significant effect of altitude and season on survival and growth of the seedlings of selected Rhododendronspecies.

\section{Materials and Methods}

\subsection{Study Site}

Arunachal Pradesh, the largest state in the northeastern region of India, located between $26^{\circ} 28^{\prime}-29^{\circ} 30^{\prime} \mathrm{N}$ latitudes and $91^{\circ} 30^{\prime}-97^{\circ} 30^{\prime} \mathrm{E}$ longitudes and covers a geographical area of $83,743 \mathrm{sq} . \mathrm{km}$. The stateis bordered by China in the north and northeast, Bhutan in west, Myanmar in east and in south by the Indian states of Assam and Nagaland. The Eastern Himalayas constitute about $84 \%$ of the total geographical area of the state. The study was carried out in a temperate broad leaved forest at Mechuka in West Siang district of Arunachal Pradesh. The West Siang district lies between $27^{\circ} 32^{\prime}-28^{\circ} 59^{\prime} \mathrm{N}$ latitude and $93^{\circ} 58^{\prime}-94^{\circ} 58^{\prime} \mathrm{E}$ longitude. The district is spread over 7,813 sq. $\mathrm{km}$ and constitutes $9.33 \%$ of the total geographical area of the state. The topography of the district is mountainous and the northern part of it falls within higher mountain zone of Himalaya consist of a mass of tangle peaks and valleys. Various ecological zones, viz. tropical, subtropical, temperate, subalpine and alpine are present in the district. The total forest cover of the district is 6,719 sq. $\mathrm{km}$ ( $86 \%$ of the total geographical area),out of which very dense forest comprises of 2,478 sq. $\mathrm{km}$, moderately dense forest $2,741 \mathrm{sq}$. $\mathrm{km}$ and open forest covers about 1,501 sq. $\mathrm{km}[42]$.

Mechuka falls under the Himalayan range and is characterized by rough topography with mountains, deeply incised valleys, escarpments and plateaus. Major areas of Mechuka are inaccessible and these areas are still covered with virgin forest. Moreover, until 2004 there was no motorable road connectivity to Mechuka. According to the climatic condition, four distinct seasons can be characterised in Mechuka. The period from December to February, maximum snowfall takes place when the temperature drop down below freezing point, represents winter. The period from March to May represents spring with little rain whereas, the period from June to September with maximum of the total annual rainfall represents rainy season (monsoon) and the period from October to November represents the autumn (post monsoon) with little shower.

For the present study, the Rhododendron forest was divided into three study stands along the altitudinal gradient viz, Shagong (1900-2100m), Hanuman camp (2100-2300m) and Yarlung $(>2300 \mathrm{~m})$. The forest is in climax stage, very old aged and dominated by Rhododendron species. The precise age of the forest is not known due to non availability of the forest history with the local forest department. Thick spongy humus layer covers the forest floor.

\subsection{Methods}

\subsubsection{Soil Physico-Chemical Properties}

Soils were collected from the three study stands and various physico-chemical properties were determined through standard procedures. The soil texture was determined by the hydrometer method, soil bulk density and porosity were determined by following the methodology given by Allen et al.[43]. Water holding capacity (WHC) was determined by Keen's box method. Soil moisture content was determined gravimetrically; $\mathrm{pH}$ was determined electrometrically by a digital $\mathrm{pH}$ meter in 1:2.5 suspension of soil in deionized water[44]. Soil organic carbon was determined according to Walkley and Black's rapid titration method[45]. Total kjeldahl nitrogen (TKN) was determined by following Allen et al.[43]. Available phosphorus was extracted from soil using the Bray and Kurtz No 1 procedure of Bray and Kurtz[46]. Exchangeable soil potassium[43] was determined by extraction of soils using $1 M$ ammonium acetate solution buffered to $\mathrm{pH} 7.0$, followed by the measurements of potash in the extracts on a flame photometer (Flame Photometer 130). Values for different soil physico-chemical variables of the three study stands are given in Table 1 .

Table 1. Physico-chemical Properties of Soil in the Three Study Stands

\begin{tabular}{|c|c|c|c|}
\hline \multirow{2}{*}{ Variables } & \multicolumn{3}{|c|}{ Study stands } \\
\cline { 2 - 4 } & Shagong & $\begin{array}{c}\text { Hanuman } \\
\text { Camp }\end{array}$ & Yarlung \\
\hline Bulk density $\left(\mathrm{g} \mathrm{cm}^{-3}\right.$ ) & 0.83 & 0.99 & 1.01 \\
\hline Porosity (\%) & 68.60 & 62.60 & 62.06 \\
\hline WHC (\%) & 63.87 & 64.68 & 65.05 \\
\hline Texture & $\begin{array}{c}\text { Sandy } \\
\text { clay loam }\end{array}$ & $\begin{array}{c}\text { Sandy } \\
\text { clay loam }\end{array}$ & $\begin{array}{c}\text { Sandy } \\
\text { clay loam }\end{array}$ \\
\hline $\mathrm{pH}$ & 4.71 & 4.41 & 4.08 \\
\hline Moisture content (\%) & 50.4 & 51.6 & 56.8 \\
\hline Organic carbon (\%) & 4.87 & 5.34 & 6.89 \\
\hline Total nitrogen (\%) & 0.15 & 0.20 & 0.25 \\
\hline Available phosphorus (\%) & 0.010 & 0.011 & 0.007 \\
\hline Exchangeable potassium & 0.42 & 0.43 & 0.37 \\
\hline
\end{tabular}

\subsubsection{Seedling Survival and Growth}

To study the survival and growth of seedlings, two Rhododendron species viz., Rhododendron kenderickii and Rhododendron grandewere selected from the three study stands (viz. Shagong, Hanuman Camp and Yarlung). Both the species occurs in the three study stands. $R$. kenderickii is 
the main dominant species in Shagong, while, it occurs as a co-dominant species in Yarlung. R. grandedominates the study stand at Hanuman Camp.

At each study stand, fifty healthy and uniform seedlings of each of the two selected Rhododendron species were randomly selected and tagged. Survival of seedlings was monitored seasonally at four months interval for a period of two years (November, 2008 to July, 2010). Another 25 healthy seedlings $(<50 \mathrm{~cm}$ height) without any damage and of uniform sizes of each of the above mentioned selected Rhododendron tree species were randomly selected at all study stands. Selected seedlings were tagged with an individual numbered aluminum tag. Seedling growth was monitored seasonally for a period of one year (November, 2009 to November, 2010) at four months interval. Stem height, collar diameter and number of leaves of all the tagged seedlings were recorded in November $\left(t_{0}\right)$, March $\left(t_{1}\right)$, July $\left(t_{2}\right)$ and November $\left(t_{3}\right)$. The periods from $t_{0}$ to $t_{1}, t_{1}$ to $t_{2}$ and $t_{2}$ to $t_{3}$ represents winter, summer and rainy seasons respectively. Non-destructive method was used for measuring seedling height, collar diameter and leaf numbers. Seedling height and collar diameter were recorded by using measuring scale and digital verniercaliper respectively. The growth rate in terms of height and collar diameter was calculated simply by subtracting the succeeding recorded values by the preceding one while, the growth in terms of number of leaves was simply counted at each sampling time.

Seasonal as well as altitudinal variation of growth rate in terms of height, collar diameter and leaf numbers of the selected species were analysed by one-way ANOVA using STATISTICA 6.

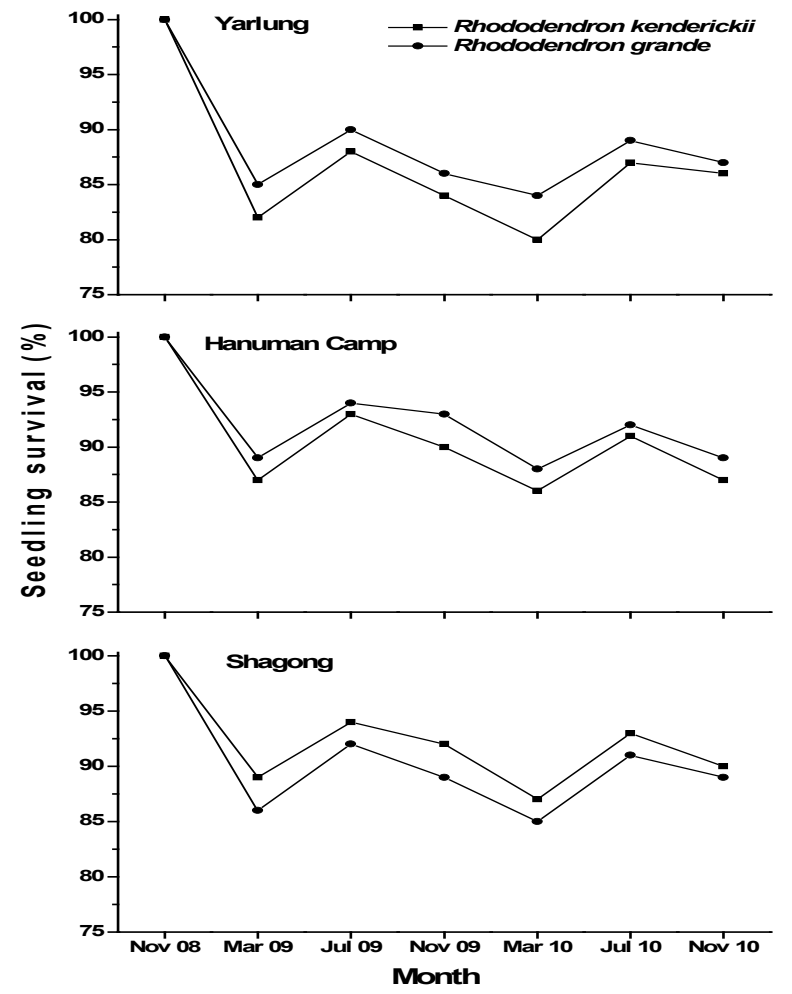

Figure 1. Seedlings survival of the two Rhododendron species in the three study stands

\section{Results}

\subsection{Seedling Survival}

High seedling mortality of both the selected Rhododendron species was recorded during the period of November to March, which experienced the cold and dry season (Figure 1). Moreover, mortality of all seedlings was recorded highest in Yarlung, which may be due to very low temperature during the winter. Seedlings survival of Rhododendron kenderickiiwas recorded better both in Shagong as well as in Hanuman Camp while, $R$. grandeshows similar trend of survivorship in all the study stands which might be due to availability of uniform favourable conditions during growing season.

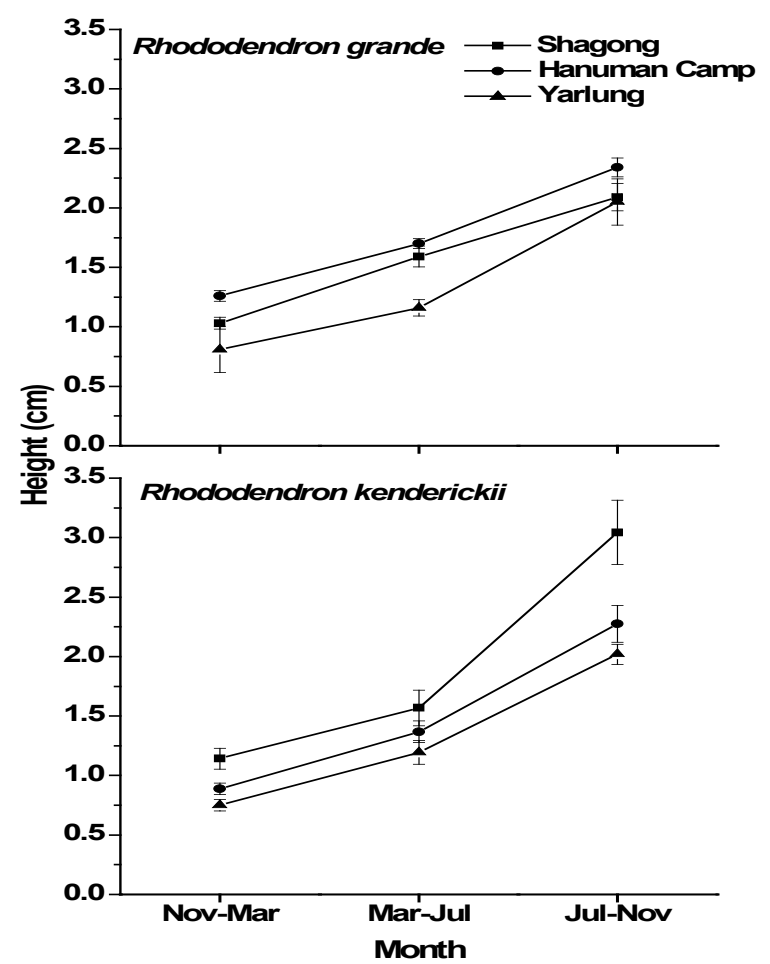

Figure 2. Seasonal growth rate of seedlings of the two Rhododendron species in terms of height in the three study stands

\subsection{Seedling Growth}

Tagged seedlings of the selected Rhododendronspecies recorded highest relative growth rate in terms of height (Figure 2), collar diameter (Figure 3) as well as mean leaf number during the rainy season and minimum in the winter. Moreover, both the selected species showed significant variations in growth rate among the study stands as well as in seasons $(\mathrm{F}=7.6$ and 39.3 respectively, $\mathrm{p}<0.001) . R$. kenderickii exhibits significant seasonal $(\mathrm{F}=68.6, \mathrm{P}<0.001)$ as well as altitudinal $(\mathrm{F}=7.7, \mathrm{P}<0.001)$ variation of relative growth rate in terms of height. However, variation of growth rate in terms of collar diameter was found significant only in seasons $(\mathrm{F}=36.3, \mathrm{P}<0.001)$. Moreover, mean leaf number of $R$. kenderickii (Figure 4) shows significant variation in different sampling periods as well as study stands $(\mathrm{F}=11.48$ and 10.40 respectively, $\mathrm{P}<0.001)$. $R$. kenderickii recorded 
highest total growth in terms of height and collar diameter in Shagong while, minimum in Yarlung (Figure 5). On the other hand, $R$. grande shows significant seasonal as well as altitudinal variation of growth rate in terms of height $(\mathrm{F}=$ 27.5. $\mathrm{P}<0.001$ and $\mathrm{F}=3.9, \mathrm{P}<0.05$ respectively) and collar diameter $(\mathrm{F}=29.7$ and 7.1 respectively, $\mathrm{P}<0.001)$ and highest growth in total height as well as in collar diameter was recorded in Hanuman Camp while, minimum in Yarlung (Figure 5). It also shows variation in mean leaf number (Figure 4) in different sampling period as well as study stands $(\mathrm{F}=29.67$ and 15.45 respectively, $\mathrm{P}<0.001)$.

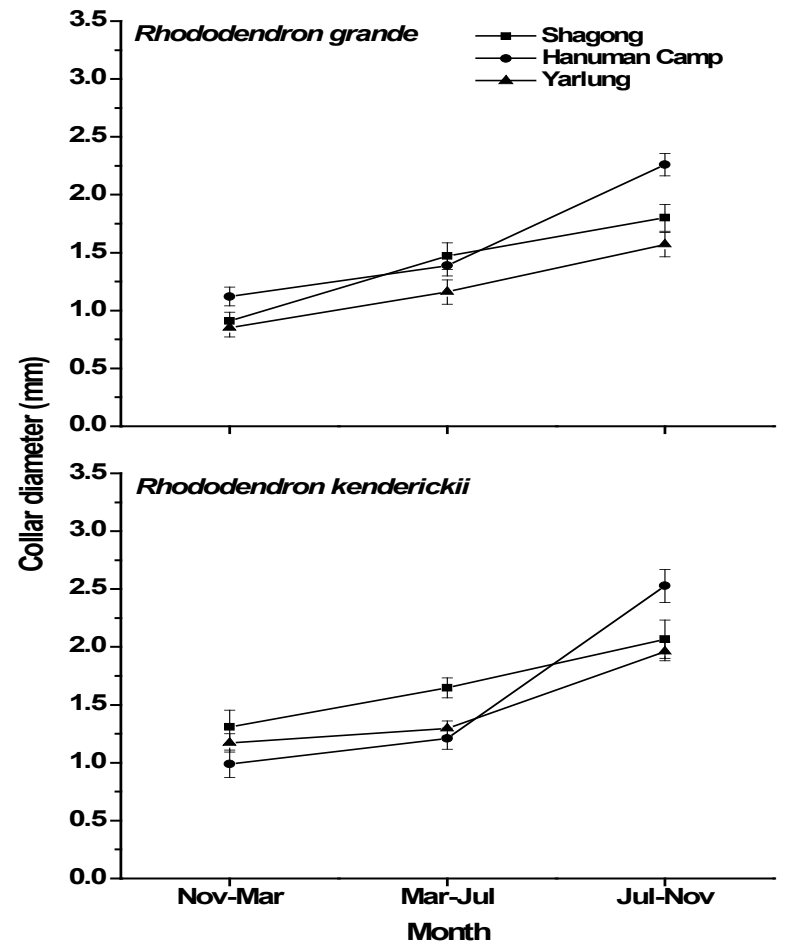

Figure 3. Seasonal growth rate of seedlings of the two Rhododendron species in terms of Collar diameter in the three study stands

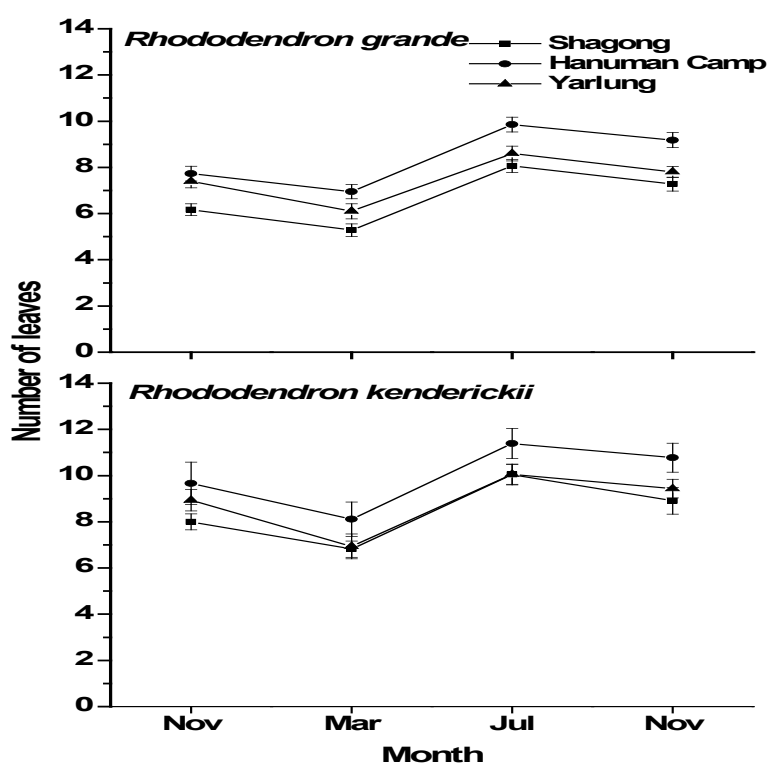

Figure 4. Growth of seedlings of the selected Rhododendron species in terms of number of leaves in the three study stands
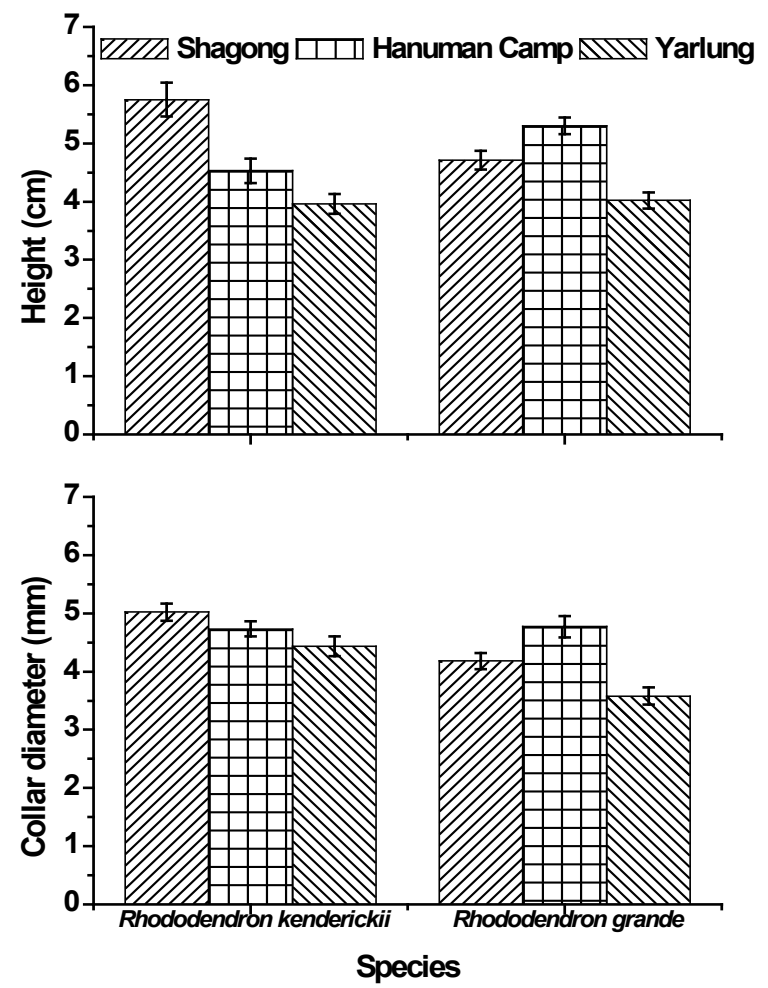

Figure 5. Total growth of seedlings of the selected Rhododendron species in terms of collar diameter and height in the three study stands

\section{Discussion}

The seedlings of both the selected Rhododendron species show high mortality during the period of November to March while, mortality rate is low during March to July. It may be due to cold and dry climatic conditions prevailing during the winter season. Paul[47] also reported high mortality of seedlings of Rhododendron arboreum, $R$. arboreum var. delavayi, $R$. barbatum and $R$. kesangiae during the dry period from temperate broad leaved forest of western Arunachal Pradesh. Similar seasonal mortality was also reported by various workers from both natural[48-50] as well as from experimental conditions[51,52]. Moreover, seedling mortality of both the selected Rhododendron species was recorded highest in Yarlung. This may be attributed to very low temperature and accumulation of ice crystals at night on the forest floor during winter and causing injury to the seedlings due to freezing desiccation and as a result affect survival[50]. Such damage occurs when the upper soil layer is frozen causing reduction of available soil moisture $[53,54]$.Moreover, very young and smaller seedlings are more prone to such damage due to low temperature. During winter the seedlings also experienced moisture stress and as a result mortality increases. The detrimental effect of soil moisture stress on the survival of tree seedlings has been reported by several workers[55-57].

McLaren and McDonald[58] reported that seedling mortality was high during the early period of the dry season which experienced an immediate reduction in rainfall, but 
seedling survival stabilized at the start of the wet season. Moreover, the forest canopy plays a major role on seedlings establishment and survival on the forest floor with changes in the availability of light and water[59-62]. The change in the ground condition created due to the formation of natural gaps in the canopy of the forest might be potentially favourable for the survival of tree seedlings as also observed by Brokaw[63]. Moreover, successful regeneration of any type of species can only occur if the right amount of growing space becomes available for the establishment and subsequent growth of seedlings[64]. Mason et al.[65] reported that the highest seedling survival was found under the widest spacing and declined with closer spacing and lower light intensity in conifer forest.During the study, it was observed that very few Rhododendron seedlings were found beneath the canopy, but they are abundant in open places like steep slopes, forest margins and bank of streams. This may be because of the reason that in these particular sites, seeds received the desired buffered moisture and temperature conditions and light levels suitable for germination and effective recruitment. Cross[66] also reported similar findings for Rhododendron ponticum from SW Ireland. Light is an absolute requirement for germination of Rhododendronseeds[67-69]. Kameyama et al.[70] reported that seedlings of Rhododendron metternichiiSieb. etzucc var. hondoenseNakai were highly dependent on ground conditions and canopy cover in Mt. Kamakuraji of Hiroshima Prefecture, Japan.

The seasonal variability in growth response is an important parameter to determine the growth of tree species in natural forest. There were increases in growth rate in height and collar diameter of all selected species attaining a peak during the rainy season. However, peaked increase in mean leaf numbers by all selected species was shown during March to July before the rainy season. Paul[47]) also reported marked increase in leaf number of Rhododendron arboreum, $R$. arboreum var. delavayi, $R$. barbatum and $R$. kesangiae during the wet period from temperate forest of Arunachal Pradesh. Jones et al.[41] and Seiwa[25,40] reported that early leaf development of seedlings promotes biomass gain through height and radial growth and enhances survival rates in temperate broad-leaved forests. Seedlings of all the species showed low growth during the months of November to March, which may be due to cold and dry winter season with high soil moisture stress. The role of soil moisture in influencing growth of seedlings has been studied by many workers[71]. The peak seedling growth during wet period could be attributed to the increased availability of nutrients due to rapid decomposition of litter on the forest floor and also to the higher moisture content of the soil. Farnsworth and Ellison[72] reported that seedling and sapling photosynthetic rates were significantly depressed in winter, while, photosynthetic rates in leaves of mature trees did not differ between winter and summer.

Differences in growth among the species are caused by morphological parameters, while, temporal changes are caused by physiological parameters[73]. Variation in height growth, collar diameter and mean leaf number of the seed- lings of selected species in the three study stands may be partly responsible for the difference in growth behavior under a given set of environmental conditions. The higher growth of seedlings of $R$. kenderickiiand $R$. grande in Shagong and Hanuman Camp respectively could be attributed to the availability of optimum growth conditions like light, temperature, moisture and edaphic factors which is required by these two species. The poor growth in Yarlung may be due to comparatively low temperature as compared to the other two study stands. Variation in micro environmental conditions in forest understorey plays important role in differential growth behavior of seedlings. Among these light is the most important factor for growth of seedlings via photosynthesis in forest understorey. Growth rates in low light have been often linked with seedling survival by many workers[74,75]. Moreover, temperature also plays major role which affects the growth rate of seedlings. It is one of the chief determinants controlling the length of the growing season. In comparison with the tropics, the temperate and boreal zones have low mean annual temperatures which result in slow growth of the seedlings, saplings and trees growing there. Within a certain range, the growth rate increases with the increase of temperature[76]. Very high temperatures do not facilitate but retard the growth rate[77]. Apart from light and temperature, some other environmental factors also play vital role in the growth of trees such as water, nutrition[78], ambient $\mathrm{CO}_{2}$ level[79], wind[80] etc. Moreover, the ontogenetic status of seedlings also affects the shoots extension growth[81], biomass partitioning[82] and shoots size and number $[83,84]$.

\section{Conclusions}

In conclusion, it may be stated that the survival and growth of seedlings of the two selected Rhododendron species were greatly influenced by altitude as well as season. High seedling mortality was recorded at the altitude of $>2300 \mathrm{~m}$, as well as during the dry season. Growth rate of all selected species were found highest during wet period of the year while, the total growth varies among the species at different study stands along the altitudinal gradient. This variability may be due to the variation in light, temperature, moisture and edaphic factors which results into development of an array of microclimatic conditions for differential growth behavior of different species.

\section{ACKNOWLEDGEMENTS}

We thank the PCCF, Arunachal Pradesh and the Additional Deputy Commissioner,Mechuka forresearch permit. Thanks also go to the local guide Mr. Changer Dree for help and cooperation during field study. The author greatly thankful to theUniversity Grant Commission, GOI, for financial support through Rajiv Gandhi National Fellowship. 


\section{REFERENCES}

[1] Hughes, F.M.R. and Rood, S.B, 2003, Allocation of river flows for restoration of floodplain forest ecosystems: a review of approaches and their applicability in Europe, Environmental Management, 32(1),12-33

[2] Li, X., Liu, W. and Tang, C.Q., 2010, The role of the soil seed and seedling bank in the regeneration of diverse plant communities in the subtropical Ailao Mountains, Southwest China, Ecological Research, 25(6), 1171-1182

[3] Fenner, M., 1987, Seedlings, New Phytologist, 106(1), 35-47

[4] Hutchings, M.J., 1997, The structure of plant populations, Plant Ecology, Crawley, M.J., ed. Blackwell Science, Oxford

[5] Augspurger, C.K., 1984, Light requirement of neotropical tree seedlings: a comparative study of growth and survival,Journal of Ecology, 72(3), 777-795

[6] Cavers, P.B., 1983, Seed demography,Canadian Journal of Botany, 61(12), 3578-3590

[7] Jones, R.H. andSharitz, R.R., 1998,Survival and growth of woody plant seedlings in the understorey of floodplain forests in South Carolina, Journal of Ecology, 86(4), 574-587

[8] Clinton, G.D., Boring, L.R. and Swank, W.T., 1994, Regeneration patterns in canopy gaps of mixed oak forests of the Southern Appalachians: influences of topographic position and evergreen understory, The American Midland Naturalist Journal, 132(2), 308-319

[9] George, L.O. andBazzaz F.A., 1999, The fern understorey as an ecological filter: emergence and establishment of canopy-tree seedlings, Ecology, 80(3), 833-845

[10] Beckage, B. and Clark, J.S., 2003, Seedling survival and growth of three forest tree species: the role of spatial heterogeneity, Ecology, 84(7), 1849-1861

[11] Burton, P.J. andBazzaz, F.A., 1991, Tree seedling emergence on interactive temperature and moisture gradients and in patches of old-field vegetation,American Journal of Botany, 78(1), 131-149

[12] Clark, J.S., Macklin, E. and Wood, L., 1998, Stages and spatial scales of recruitment limitation in Southern Appalachian forests, Ecological Monographs, 68(2), 213-235

[13] Kobe, R.K., 1999, Light gradient partitioning among tropical tree species through differential seedling growth and mortality, Ecology, 80(1), 187-201

[14] Beckage, B., Clark, J.S., Clinton, B.D. and Haines, B.L.B., 2000, A long-term study of tree seedling recruitment in southern Appalachian forests: the effects of canopy gaps and shrub understories, Canadian Journal of Forestry Research, 30(10), 1617-1631

[15] Bongers, F. and Popma, J., 1988, Trees and gaps in a Mexican tropical rain forest; species differentiation in relation to gap-associated environmental heterogeneity, Utrecht University, Utrecht, The Netherlands

[16] Burslem, D.F.R.P., Grubb, P.J. and Turner, I.M., 1995, Responses to nutrient addition among shade-tolerant tree seedlings of lowland tropical rain forest in Singapore, Journal of Ecology, 83(1), 113-122
[17] Potvin, M.A., 1993, Establishment of native grass seedlings along a topographic/moisture gradient in the Nebraska sandhills, American Midland Naturalist, 130(2), 248-261

[18] Ashton, P.M.S., Gunatilleke, C.V.S. andGunatilleke, I.A.U.N., 1995, Seedling survival and growth of fourShorea species in a Sri Lankan rain forest. Journal of Tropical Ecology, 11(2), 263-279

[19] McCarthy, B.C. andFacelli, J.M., 1990, Microdisturbances in oldfields and forests: implications for woody seedlings establishment, Oikos, 58(1): 55-60

[20] Kobayashi, M. andKamitani, T., 2000,Effects of surface disturbance and light level on seedling emergence in a Japanese secondary deciduous forest, Journal of Vegetation Science, 11(1), 93-100

[21] Titus, J.H. and del Moral, R., 1998, Seedling establishment in different microsites on Mount St. Helens, Washington, USA, Plant Ecology, 134(1), 13-26

[22] Denslow, J.S. and Guzman, G.S., 2000, Variation in stand structure, light and seedling abundance across a tropical moist forest chronosequence, Panama, Journal of Vegetation Science,11(2), 201-212

[23] Facelli, J.M., 1994, Multiple indirect effects of plant litter affect the establishment of woody seedlings in old fields, Ecology, 75(6), 1727-1735

[24] Seiwa, K. andKikuzama, K., 1996, Importance of seed size for the establishment of seedlings of five deciduous broad-leaved tree species, Vegetatio, 123(1), 51-64

[25] Seiwa, K., 1997, Variable regeneration behaviour of $U l$ musdavidiana var. japonica in response to disturbance regime for risk spreading, Seed Science Research, 7(2), 195-207

[26] Pacala, S.W., Canham, C.D., Saponara, J., Silander, J.A. Jr., Kobe, R.K. andRibbens E., 1996,Forest models defined by field measurements: estimation, error analysis and dynamics, Ecological Monographs, 66(1), 1-43

[27] Coomes, D.A. and Grubb, P.J., 2000, Impacts of root competition in forests and woodlands: a theoretical framework and review of experiments, Ecological Monographs, 70(2), 171-207

[28] Canham, C.D., 1988, Growth and canopy architecture of shade tolerant tree: the response to canopy gaps. Ecology,63(3), 786-795

[29] Platt, W.J. and Strong, D.R., 1989, Gaps in forest ecology, Ecology, 70(3), 535-576

[30] Pacala, S.W., Canham, C.D., Silander, J.A. Jr. and Kobe, R.K., 1994, Sapling growth as a function of resources in a north temperate forest, Canadian Journal of Forest Research, 24(11), 2172-2183

[31] Clark, D.A. and Clark, D.B., 1992, Life history diversity of canopy and emergent trees in a Neotropical rain forest, Ecological Monographs, 62(3), 315-344

[32] Clark, D.A., Clark, D.B., Rich, P.M., Weiss, S. andOberbauer S.F., 1996, Landscape-scale evaluation of understorey light and canopy structure: methods and application in a neotropical lowland rain forest, Canadian Journal of Forest Research, 26(5), 747-757 
[33] Rossi, B.E. andVillagra, P.E., 2003, Effects of Prosopisflexuosa on soil properties and the spatial pattern of understorey species in Arid Argentina, Journal of Vegetation Science, 14(4), 543-550

[34] Puerta-Pinero, C., Gomez, J.M. and Zamora, R., 2006, Species specific effects on topsoil development affect Quercus ilex seedling performance,ActaOecologica, 29(1), 65-71

[35] Tripathi, R.S. and M.L., Khan, 1990, Effects of seed weight and micro-site characteristics on seed germination and seedling fitness in two species of Quercus in a subtropical wet hill forest,Oikos, 57(3), 289-96

[36] Dzwonko, Z. andGawronski, S., 2002, Influence of litter and weather on seedling recruitment in a mixed oak pine woodland, Annals of Botany, 90(2), 245-251

[37] Khurana, E. and Singh, J.S., 2001, Ecology of seed and seedling growth for conservation and restoration of tropical dry forest: a review, Environmental Conservation, 28 (1), $39-52$

[38] Kikuzawa, K., 1983, Leaf survival of woody plants in deciduous broad-leaved forests, Canadian Journal of Botany, 61(8), 2133-2139

[39] Lechowicz, M.J., 1984, Why do temperate deciduous trees leaf out at different times? Adaptation and ecology of forest communities, The American Naturalist, 124(6), 821-842

[40] Seiwa, K., 1998,Advantages of early germination for growth and survival of seedlings of Acer mono under different overstoreyphenologies in deciduous broad-leaved forests, Journal of Ecology, 86(2), 219-228

[41] Jones, R.H., Allen, B.P. andSharitz, R.R., 1997, Why do early-emergence tree seedlings have survival and advantages? A test using Acer rubrum (Aceraceae). American Journal of Botany, 84(12), $1714-1718$

[42] FSI 2009, State of Forest Report, Ministry of Environment and forest, Govt. of India, Dehra Dun

[43] AllenS.E., Grimshaw, H.M., Parkinson, J.A. and Quarmby, C., 1974, Chemical analysis of ecological materials, Allen S.E. eds. Blackwell Scientific Publications, Oxford

[44] Anderson, J.M. and Ingram, J.S.I., 1993, Tropical soil biology and fertility - a handbook of methods, 2nd ed., CAB International, Wallingford, UK

[45] Walkley, A. and Black, I.A., 1934,An examination of the Detjareff method for determining soil organic matter and a proposed modification of the chromic acid filtration method. Soil Science, 37, 29-38

[46] Bray, R.H., Kurtz, L.T., 1945, Determination of total, organic, and available forms of phosphorus in soils, Soil Science, 59: $39-45$.

[47] Paul, A., 2008, "Studies on diversity and regeneration ecology of Rhododendrons in Arunachal Pradesh," Ph.D. thesis, Assam University, Silchar, India

[48] Swaine, M.D., Lieberman, D. and Hall, J.B., 1990, Structure and dynamics of a tropical dry forest in Ghana, Plant Ecology, 88(1), 31-51

[49] Lieberman, D. and Li, M., 1992, Seedling recruitment patterns in a tropical dry forest in Ghana, Journal of Vegetation
Science, 3(3), 375-382

[50] Granhus, A., Hanssen, K.H. and de Chantal, M., 2008,Emergence and seasonal mortality of naturally regenerated Piceaabies seedlings: impact of overstorey density and two site preparation methods, New Forests, 35(1):75-87

[51] Gerhardt, K., 1993, Tree seedling development in tropical dry abandoned pasture and secondary forest in Costa Rica, Journal of Vegetation Science, 4(1), 95-102

[52] Bowers, J.E. and Turner, R.M., 2002, The influence of climatic variability on local population dynamics of Cercidiummicrophyllum (foothill paloverde), Oecologia, 130(1),105-113

[53] Krasowski, M.J., Letchford, T., Caputa, A., Bergerud, W.A. andOtt, P.K., 1996, The susceptibility of white spruce seedlings to overwinter injury and their post-injury field responses, New Forests, 12(3), 261-278

[54] Grossnickle, S.C., 2000,Ecophysiology of Northern spruce species: the performance of planted seedlings. NRC Press, Ottawa

[55] Khan, M.L., Rai, J.P.N. andTripathi, R.S., 1986, Regeneration and survival of tree seedlings and sprouts in tropical deciduous and sub-tropical forests of Meghalaya, India, Forest Ecology and Management, 14(4), 293-304

[56] Khan, M.L. andTripathi, R.S., 1991, Seedling survival growth of early and late successional tree species as affected by insect herbivory and pathogen attack in sub-tropical humid forest stands of north-east India,ActaEcologica, 12(5), 569-579

[57] Kikim, A.D., 1999, "Vegetation dynamics and regeneration of some trees in sub-tropical forests of Manipur," Ph.D. thesis, Manipur University, Manipur, India

[58] McLaren, K.P. and McDonald, M.A., 2003, The effects of moisture and shade on seed germination and seedling survival in a tropical dry forest in Jamaica, Forest Ecology and Management, 183(1-3), 61-75

[59] Sack, L., Grubb, P.J. and Maranon, T., 2003, The functional morphology of juvenile plants tolerant of strong summer drought in shaded forest understories in southern Spain, Plant Ecology, 168(1): 139-163

[60] Sanchez-Gomez, D., Valladares, F. and Zavala, M.A., 2006, Performance of seedlings of Mediterranean woody species under experimental gradients of irradiance and water availability: trade-offs and evidence for niche differentiation, New Phytologist, 170(4), 795-806

[61] Quero, J.L., Villar, R., Maranon, T. and Zamora, R. 2006, Interactions of drought and shade effects on seedlings of four Quercus species: physiological and structural leaf responses, New Phytologist, 170(4), 819-834

[62] Garcia, L.V., Maltez-Mouro, S., Perez-Ramos, I., Freitas, H. and Maranon, T., 2006, Counteracting gradients of light and soil nutrients in the understorey of Mediterranean oak forests, Web Ecology, 6, 67-74

[63] Brokaw, N.V.L. 1984, Gap-phase regeneration in a Panamanian forest, Tropical rain forest. Chadwick, A.C. and Sutton, S.L. ed. Leeds Philosophical and Literary Society, Central Museum Calverley Street, UK

[64] Klinka, K., Carter, R.E. and Feller, M.C., 1990, Cutting 
old-growth forests in British Columbia: Ecological considerations for forest regeneration, Northwest Environmental Journal, 6(3), 221-242

[65] Mason, W.L., Edwards, C. and Hale, S.E., 2004, Survival and early seedling growth of conifers with different shade tolerance in a Sitka spruce spacing trial and relationship to understorey light climate, Silva Fennica, 38(4), 357-370

[66] Cho, M.S., Jung, J.H. andYeam, D.Y., 1981, Studies on seed germination of rhododendron plants, Journal of the Korean Society of Horticultural Science, 22(2), 107-120

[67] Blazich, F.A., Warren, S.L., Starrett, M.C. andAcedo, J.R., 1993, Seed germination of Rhododendron carolinianum: influence of light and temperature, Journal of Environmental Horticulture, 11, 55-58

[68] Rowe, D.B., Blazich, F.A., Warren, S.L. andRanney, T.G., 1994, Seed germination of three provenances of Rhododendron catawbiense: influence of light and temperature, Journal of Environmental Horticulture, 12(3), 155-158

[69] Kameyama, Y., Nakagoshi, N. andNehira, K., 1999, Safe site for seedlings of Rhododendron matternichii var. hondoense, Plant Species Biology, 14(3), 237-242

[70] Mueller-Dombois, D., Jacobi, J.D., Cooray, R.G., and Balakrishnan, N., 1980, Ohia rain forest study: ecological investigations of the Ohia dieback problem in Hawaii, Miscellaneous Publication 183, Hawaii Institute of Tropical Agriculture and Human Resources, Honolulu, HI

[71] Farnsworth, E.J. and Ellison, A.M., 1996, Sun-shade adaptability of the red mangrove, Rhizophora mangle (Rhizophoraceae): changes through ontogeny at several levels of biological organization, American Journal of Botany, 83(9), 1131-1143

[72] Isabel, A., Emilio, C.R. and Rafael, V., 2001, Relative growth rate in phylogenetically related deciduous and evergreen woody species,Oecologia, 128(2), 172-180

[73] Walters, M.B. and Reich, P.B., 1996, Are shade tolerance, survival and growth linked? Low light and nitrogen effects on hardwood seedlings, Ecology, 77(3), 841-853
[74] Walters, M.B. and Reich, P.B., 2000, Seed size, nitrogen supply, and growth rate affect tree seedling survival in deep shade, Ecology, 81(7), 1887-1901

[75] Sheu, B.H. and Lin, C.K., 1999, Photosynthetic response of seedlings of the sub-tropical tree Schimasuperba with exposure to elevated carbon dioxide and temperature, Environmental and Experimental Botany, 41(1),57-65

[76] McInnis, B.G. and Roberts, M.R., 1995, Seedling microenvironment in full-tree and tree-length logging slash, Canadian Journal of Forest Research, 25(1), 128-136

[77] Kozlowski, T.T., Kramer, P.J. and Pallardy, S.G., 1991, The physiological ecology of woody plants. Academic Press, USA

[78] Norby, R.J., Wullschleger, S.D., Gunderson, C.A., Johnson, D.W. andCeulemans, R., 1999, Tree responses to rising $\mathrm{CO}_{2}$ in field experiments: implications for the future forest, Plant, Cell \& Environment, 22(6), 683-714

[79] Cordero, R.A. 1999,Ecophysiology of Cecropiaschreberiana saplings in two wind regimes in an elfin cloud forest: growth, gas exchange, architecture and stem biomechanics, Tree Physiology, 19(3), 153-163

[80] Centritto, M., Lee, H.S.J. and Jarvis, P.G., 1999,Long term effects of elevated carbon dioxide concentration and provenance on four clones of Sitka spruce (Piceasitchensis). I. Plant growth, allocation and ontogeny, Tree Physiology, 19(12), 799-806

[81] King, J.S., Albaugh, T.J., Allen, H.L. and Kress, L.W., 1999, Stand-level allometry in Pinusteada as affected by irrigation and fertilization, Tree Physiology, 19(12), 769-778

[82] Chazdon, R.L., 1991, Plant size and form in the understorey, palm genus Geonoma: Are species variations on a theme? American Journal of Botany, 78(5), 680-694

[83] Ritchie, G.A. andKeeley, J.W., 1994,Maturation in Douglas-fir: I. Changes in stem, branch and foliage characteristics associated with ontogenetic aging, Tree Physiology, 14(11), $1245-1259$ 